\title{
Why do innovators not apply for trademarks? The role of information asymmetries and collaborative innovation
}

\author{
Suma Athreye \\ Essex Business School \\ Elmer Approach, \\ Southend on Sea SS1 1LW \\ Claudio Fassio \\ Lund School of Economics and Management \& \\ CIRCLE, Lund University \& \\ BRICK, Collegio Carlo Alberto
}




\title{
Why do innovators not apply for trademarks? The role of information asymmetries and collaborative innovation
}

\begin{abstract}
This paper analyses the underlying reasons why innovators do not apply for trademarks for all of their valuable inventions. Using a unique database of UK innovations linked to innovative firms, the empirical analysis highlights the many ways that firms can alleviate information asymmetries and the constraints imposed by collaborative innovation without taking recourse to trademarks. When information asymmetries are not at stake, i.e. when firms use an already existing trademark for their innovations or when they use intermediaries for its distribution, trademarks no longer serve their purpose, leading firms to avoid using it for their innovations. Open innovation also decreases the incentive to trademark, especially when the innovative process involves users, mainly because of property rights issues or because the innovator prefers to use the clients' own distribution channels.
\end{abstract}

Key words: Trademarks, innovation, intellectual property, open innovation

JEL codes: O31, O34 


\section{Introduction}

Trademarks are something (such as a word) that identifies a particular company's product and cannot be used by another company without permission. They can apply to a single product, groups of product and to goods or services. In the innovation literature trademarks have been often compared with patents, since they can be both used to protect the returns from innovation. However, while patents and trademarks share the characteristic of exclusivity, and are often administered by the same entity, trademarks protect a quite different market failure than do patents. Trademarks help consumers identify the product produced by a firm in a crowded marketplace and such become relevant when firms have a clearly identified a market for their innovation. The market failure they address is the presence of asymmetric information between buyers and sellers. In the case of patents and copyright, the market failure addressed arises from the public good nature of technology and the need to protect the returns to inventive and creative output.

WIPO (2013: 87) notes that trademarks are the most widely used form of Intellectual Property and are much more popular than patents. Consistent with the observation about the difference in the market failures corrected by patent and trademarks, in their empirical assessment they find trademark use is not limited to firms that operate at the technology frontier, or to sectors that witness rapid technological progress - instead firms in almost every sector of the economy employ trademarks to protect the exclusivity of their brands.

Furthermore, they note that trademarks are far cheaper to apply for than patents and firms can use them forever, as long as they renew the trademark.

Although, trademarks per se do not require the company's product to be innovative or novel, a number of recent studies suggest that innovators do use trademarks more often than other kinds of firms (Mendonca et al., 2004; Jensen and Webster, 2009; Götch and Hipp, 2012). What lies behind this widely observed correlation? The clearest rationale for this is provided by the work of Greenhalagh and Rogers (2012) who argue that when product innovations fall short of novelty but incorporate several small improvements in product characteristics, firms may use trademarks to protect such improvements. Similarly, innovations that cannot be protected by patents (such as services) may take recourse to protection by trademarks. Greenhalagh and Rogers (2012) find that trademark stocks influence value added and market value in a manner qualitatively similar to patents, thus strengthening the argument that trademarks may be used by innovating firms in a manner similar to patents in order to protect their incremental product innovations.

Since trademarks are used as a method to protect the market for incremental innovations and service innovations, it may be worth asking why every innovator does not use them as they are so much cheaper to obtain than patents and deliver the same advantages of exclusivity for a longer period of time. Put differently, why are innovations sometimes not associated with trademarks? This is the question we study in this paper drawing on unique and novel survey data from 2015.

Unlike, previous studies that have typically used trademark filings by a firm, the survey data we use elicits responses from innovators about the protection of their most commercially most valuable innovation and the reasons for not patenting or trademarking that innovation. 
This is useful for two reasons- first a very valuable innovation is the one a firm is most likely to protect with patent and /or trademarks. Second, it helps us disentangle the firm level and innovation level attributes that are associated with trademarking or not trademarking.

The reasons for not trademarking are less understood in the literature and we believe our paper is the first to provide any empirical estimates of them. We find the most important reason for not trademarking an innovation was because the innovator had already protected the market in other ways, such as through the use of alternative distribution channels, or through an existing trademark. Secondly, we find collaborative innovation with clients may be associated with much lower numbers of trademark applications - both because the innovation was too bespoke to be offered generally and because there may have been agreements in place to prevent the innovator from using trademarks.

The remainder of this paper is organised in the following way: Section 2 briefly reviews the literature on trademark protection and literature that finds a linkage between trademark application and innovativeness of firms. Section 3 describes the data and methods employed in our analysis. Section 4 describes the data and section 5 reports on the results of the multivariate analysis. Section 6 concludes.

\section{Innovators and trademark applications}

The rationale for a trademark is believed to be information asymmetry between buyer and seller (Landes and Posner 1987) and as such trademarks secure customer loyalty for some perceived qualities associated with the products of the firm. This theory directly suggests that trademarks signal the distinctiveness of the production origins of a product. However, in their paper surveying developments in the economics and law of trademarks, Ramello and Silva (2006) note that in practice, trademarks had moved beyond signalling 'source distinctiveness" to offering "differential distinctiveness".

Differential distinctiveness refers to product differentiation in the market place that may be attributed to particular firms. This differentiation may involve completely new attributes of a product being developed as suggested by Fosfuri and Giratana (2009) or it may involve an improvement of existing attributes and incremental innovation as studied by Greenhalgh and Rogers (2012). Thus, trademarks act as both an exclusionary device and a source of new advertising (and product information) in a contested marketplace, which in turn draws the attention of potential consumers to the new product innovation. In this sense, trademarks are a precursor to creating brands and goodwill - two important intangible assets that a firm may possess. These assets are of course, very complementary to other intangible assets possessed by innovative firms such as patents and reputation. Thus it should come as no surprise that several empirical studies have found innovating firms to invest in trademarks.

As Greenhalgh and Rogers (2012) note, even the static 'signalling of asymmetric information model' contains the idea that trademarks may encourage firms to invest in improving the quality of their products. Thus, when exploring the reasons why firms may not trademark their innovations it may be useful to start with the information asymmetry lens as we do below. But we believe information asymmetry may not be enough of reason to explain why firms do not always trademark innovations. This is because a large proportion of modern day 
innovators are service firms who innovate through collaboration with suppliers and clients. While Miozzo et al (2016) show that despite the low priority given to formal appropriation methods service firms do tend to use trademarks and patents much more during collaborative innovation, Desylles et al (2018) find that innovations from the service sector are heterogeneous and this heterogeneity has implications for the use of patents and trademarks. In particular they find cost oriented service firms may accord more importance to formal appropriability but product differentiation oriented service firms "may generate clientspecific innovations which are sufficiently protected through resource immobility, causal ambiguity and/or competitors' lack of absorptive capacity to not require formal protection. We thus also explore the effect of openness on a innovators decision not to trademark for all valuable innovations.

\section{1: Trademarks, information asymmetry and innovative products}

The extent of information asymmetry between buyer and seller may be high when firms introduce new technological products or improve the characteristics associated with their product innovations. The nature of the technology may be unknown and the buyer may not always associate the firm with that product and so firms that desire the loyalty of their old customers may prefer to register a new trademark. Thus, if the technology product market is marked by information asymmetry between buyer and seller about the quality or reliability of the product, then we may expect firms to overcome this problem by using a trademark. Indeed, consistent with this reasoning Flikkema et al (2014) find that most trademarks are applied for in the later (marketing) phases of the innovation process.

A wide range of empirical studies confirm this theoretical proposition between the information asymmetry caused by a new (technological) product and the use of trademarks. Thomä and Bizer, (2013) show that trademarks are more frequently used in markets with competition based on product differentiation rather than price. Many studies find robust evidence of a positive association between trademarks and, respectively, R\&D intensity ( see Allegrezza and Guard-Rauchs 1999) and innovation activities at the firm level ( see Schmoch 2003, Greenhalgh and Rogers 2012 and Götsch and Hipp 2012), strongly suggesting indeed that many innovative firms do make use of trademarks. The use of trademarks has also been pronounced for some types of innovation that cannot be patented, such as innovative activities in services. Knowledge Intensive Business Sectors, companies might rely on trademarks as a preferred way of protecting their intellectual property embedded in their products (Schmoch, 2003; Amara et al., 2008; Castaldi, 2018).

In the same context of product innovation, looking at trademarking from the lens of information asymmetry between buyer and seller also suggests some reasons when trademarking may not be required. There are two distinct scenarios to consider here viz. when an information asymmetry problem between buyer and seller does not exist and when the information asymmetry issue is resolved in other ways.

Trademarks often refer to all the commercialized products of a firm. Hipp and Grupp (2005) point out that products or services containing no innovation at all (in terms of product characteristics) can be protected by a trademark, differently from what concerns patent application. Thus Amazon and Walmart are important trademarks used by trading companies 
but which do not have any innovations associated to the trademark. This does not mean of course, the companies were not innovative but their innovation rested on having innovation in the field of business related computer services which were not easy to protect through patents. Equally some sorts of trademarks have no innovation associated with them (e.g Wedgewood porcelain). Thus, while there is some kind of correlation between innovating firms and trademark application, it may not imply causation.

Flikkema et al. (2017) recognise that while trademarks can be of different types (brand extending, brand creation, brand modernizing) and while in some cases they can be related to the introduction of a new product (innovation), in some other cases this might not be the case. Moreover a firm can also choose to simply adopt an existing brand/trademark for a new product in order to benefit from the existing reputational factor associated with it. For example, Microsoft has been diversifying its product lines to include video game consoles, consumer electronics and digital services - but has not sought a new trademark. (It might however have applied for patents to protect its new technology). Thus, there are numerous examples which suggest that a firm's market for technological products may be protected by pre-existing trademarks and in such cases they may not apply for a new trademark for their innovations.

While large firms with several products may have less to gain by adding an additional trademark, as their product may already be covered by existing trademarks, as trademark are relatively cheap to obtain (for example compared with the costs of filing for a patent) and in many cases can cover a number of products, we should expect innovative small firms to apply for trademarks in larger numbers. For the UK, there is compelling evidence in Rogers et al (2007) that shows that small firms are more likely to use trademarks than other kinds of firms. Helmers et al. (2011) also suggest many firms start by applying for trademarks and then go on to file for patents later in their life. Yet clear evidence about the propensity to trademark and firm size is lacking — as WIPO (2013) notes that despite the comparatively low costs of trademark filing only about half of all start-ups in technology sectors actually file trademarks.

An important reason why small firms may not trademark extensively or do so much later in their history may be related to the use of alternate channels of marketing. Trademarks are used when a firm directly markets to the end customer, as a means of identifying its own products. Yet, small firms may reach this point relatively late in their company's history. Very often products are marketed to end consumers through wholesalers, retailers and agents. He et al. (2018) argue that the most popular channels of marketing the exports of SME are agents and distributors or partners in the host country, as the SME firm may itself lack the resources and market orientation to do so. These alternative channels are more likely to provide information about their client's product to the customer and also collect information about customer reactions to feed back to the firm. In this case the firm using them does not require trademarks as the problem of asymmetric product information vis-à-vis buyers is likely to be resolved through the choice of marketing channels.

On the basis of the above consideration it seems likely then to observe a decreased propensity to trademark innovations by firms, when they can use existing and well-established 
trademarks for their new products, or when they use alternative marketing channels, such a intermediaries, selling agents or distributors.

\subsection{Collaborative innovators and trademark applications}

The propensity to trademark an important innovation can also be affected by the specific process through which the innovation has been developed. Openness of the innovative process is seen as a factor that is likely to affect this propensity and that has not been explored in the existing trademark literature. While many studies have investigated the relationship between open innovation and the propensity to patent (Laursen and Salter, 2014; Arora et al., 2016), few studies have explored the role of collaborative innovation on the propensity to trademark.

When collaboration for innovation is upstream with suppliers, it is likely that firms will use patents to protect the technology around the innovation, but the final markets they sell their products in may not come into play. Considering the role of trademarks as an activity that is performed in later stages of the invention process (i.e. marketing and commercialization) it is particularly interesting to investigate what happens to trademark propensity when innovative collaboration are established by the innovating firms with its own users/customers.

When collaboration is downstream with clients, we may distinguish between two distinct situations. The first case is when the innovation is bespoke and responds to some client's need, but is unlikely to result in a market in the traditional sense (with many other buyers). Here there is no information asymmetry and the need to trademark does not arise. Second, when the market is general and the innovation is developed together with users, the innovators may have the incentive to use trademarks but may nevertheless face several constraints. One type of constraint is that the innovating firm might not own completely the property rights of the innovation developed and may be contractually prevented from applying for a trademark. Very large firms may be able to overcome this limitation through contracts. For example, ARM collaborates with its RISC chip clients but reserves the right to incorporate all the information gathered into improvements in its RISC chips without specific attribution to any particular client. Alternatively, the innovator's customers might be more able at appropriating the market rents from innovation, since they know the market better. The innovator may hence end up selling their innovation through the customer's distribution channels. This is common in the pharmaceutical sector: for many years Ranbaxy had a contract to sell its licensed generic drugs through Eli-Lilly's distribution channels in America (Bhandari, 2005). Though the company had a trademark, it was not well recognised in the US and so it sought this way to overcome the problem of information asymmetry with the buyers.

Thus our analysis suggests that collaborative innovation with clients, may be associated with fewer opportunities for trademarking the innovative product. Furthermore, the reasons for not trademarking may be due to the bespoke nature of the innovation or for contractual reasonsboth of which may mean that a trademark is not possible- or because the client has better distribution channels, which the innovators may also use. 


\section{Data and methods}

The propensity to trademark, in the context of the present study, refers to the probability that a firm will trademark any given innovation. An important limitation of existing empirical studies on trademark propensity is that they use firm level data, which typically indicates a positive correlation between innovativeness of companies and use of trademarks, but we cannot find evidence of a one-to-one relationship between the innovation of the company and trademark use. Recent studies (Flikkema et al., 2014) using trademark-level data allows a partial redress of this issue as they look directly at innovations that are protected by trademarks. However since trademark application is extremely cheap and product novelty is not a prerequisite for trademark applications, also these studies have a hard time identifying trademarks that protect real and valuable innovations, from other less relevant (and less innovative) products.

We use a unique dataset, which directly asks innovative firms to identify their most valuable innovation and then asks them whether they have protected it with a trademark (or a patent) - thus directly correcting for many of the identified issues. ${ }^{1}$ For those innovators who did not apply for a trademark the survey specifically asks them to indicate the reasons why they have not done so. This procedure allows a step forward with respect to existing studies on the propensity to use trademarks for innovations, as it provides data at the invention level and it also focuses on products and processes that have a high commercial value for the firm -those innovations where protection is most likely to be sought.

\subsection{Data}

The Survey of Innovation and Patent Use 2015 (henceforth SIPU 2015) was administered to all those respondents in the UKIS 2015 (CIS9) who consented to answer questions about their single most valuable innovation. This provided a total eligible sample of 886 businesses. 477 (54\%) of these businesses had specifically indicated on the UKIS 2015 that they had engaged in product, process or business strategy forms of innovation activity in the period 1 January 2012 to 31 December 2014. The survey achieved a response rate of $72 \%$ with 277 innovators and 291 non-innovators.

Figure 1 and 2 below compare the sample achieved by SIPU2015 to the CIS2015. In Figure 1, we see that SIPU over-sampled the small firms but under-sampled medium and large firms in comparison to the UK CIS. Figure 2 shows that SIPU over-sampled innovative firms overall, but also oversampled product innovators vis-à-vis the CIS.

[ Figure 1 and 2 here]

Table 1 reports the industry distribution in SIPU and CIS. SIPU over-sampled manufacturing of all types in comparison to CIS 2015 but it under-sampled construction hotels and restaurants and all types of services, generally, including professional services. To

\footnotetext{
${ }^{1}$ Firms that reported a valuable innovation were asked 'Did you apply for a trademark for that innovation?', followed by 'Did you apply for a patent for that innovation?'. We found only 35 firms of 277 had applied for both.
} 
the extent that manufacturing firms are more likely to use patents and trademarks - this may influence our aggregate results.

[Table 1 here]

\section{Trademark propensity of different groups of firms}

In order to understand why firms do not always use trademarks for their innovations, we start by identifying which are the factors that in our sample of firms are associated (or not) with the decision to apply for a trademark. We introduce a number of innovation-specific factors that we believe are likely to be correlated with the decision of the firm to use a trademark for such innovation. These include the type of innovation (product or process innovation) and the degree of novelty. We believe that firms will not have the same propensity to trademark different types of innovation, for example process innovation may be less likely to be associated to a trademark. Also the novelty of the innovation may have an impact, although we expect a somehow weaker (positive) relationship than in the case of patents as we think trademarks are preferred for incremental product innovations.

We control for the characteristics of the inventive process (open or closed innovation, the presence or not of external financing), as we think these might have important implications on the probability to use trademark or not. We are also able to control for the specific type of external partners involved (customers, suppliers, etc.) in developing the valuable innovation.

Lastly, we include a number of firm-level characteristics that, as noted in section 2.1., have been found to influence the general propensity of a firm to trademark the innovation: these include the size of the firm, the presence of $R \& D$ expenditures, and the overall patent propensity.

\section{Methodology and variables used}

We start by examining how the descriptive statistics of the average propensity of firms to trademark changes across different characteristics, and checking whether firms that differ in some of these features display a different propensity to trademark their most valuable innovation. We then translate these initial descriptive results in a multivariate context, by employing a simple probit analysis on the probability that a firm applies for a patent. This allows us to obtain a conditional mean of the trademark propensity, net of all the above mentioned factors that might influence the firms' decision.

In our probit analysis the dependent variable is a dummy variable built on the basis of the answer to the SIPU2015 questionnaire, equal to 1 if a firms applied for a trademark for its most valuable innovation and zero otherwise. The sample of firms for which we can perform our analysis corresponds to the 277 innovators who answered to the SIPU survey. The explanatory variables used in the analysis are based on the innovation specific answers of firms to the SIPU2015 questionnaire (where firms focused on their most valuable innovation), as well as on the firm specific answers to the CIS9 data. This allows us to include both types of control variables in our model specification. The specific questions used in the SIPU questionnaire are attached as an appendix to this paper. These refer to the specific nature of innovation (product, process or business strategy), the presence of external 
financing for the specific innovation, the specific value of the innovation, and the level of openness of the innovative process, distinguishing between collaboration with suppliers, clients or other types of actors. Moreover the use of the CIS frame to collect data on the most valuable innovation in SIPU allows us to match the two questionnaires and control for a rich variety of firm characteristics. These include: firm size, investments in Research and Development activities, industrial sector of affiliation, as well as the proportion of innovations protected by patents. Table 2 below details the variables we constructed more fully.

Our methodology allows identification of the characteristics that are associated with the decision to apply for a trademark for the most important innovation of a company. However, since we do not implement an empirical strategy that allows for a causal interpretation of our results, we cannot rule out the possibility that omitted variables or reverse causality issues affect our estimates. In some cases the decision to trademark (or not) an innovation might be co-determined at the moment in which the innovation process is started. For example, a firm may make the decision to adopt an open innovation strategy and to apply (or not) for a trademark simultaneously. Thus, our results should not be interpreted as a strong evidence of the existence of causal relationships.

[Table 2 here]

\section{Results}

Table 3 reports the frequency of firms applying for a trademark (or a patent) for their innovations in SIPU 2015 and in CIS9. The SIPU data are innovation specific, they only refer to the most significant innovation, while the CIS data are firm specific. The table also looks at different groups of firms to assess how this proportion varies. Although our interest is primarily in trademark usage, we also report the results for patenting as a benchmark and also in order to account for the correlation between both forms of innovation protection, stressed by many recent studies (Flikkema et al., 2017).

According to the CIS data, more firms apply for trademarks when compared to patents. Thus, about 3 in 10 innovators will apply for a trademark while only over a quarter of firms patent their most valuable innovation. Interestingly this pattern is different when we use SIPU data to look at the most valuable innovation of a firm. The proportion of firms patenting still stays a quarter but the proportion of firms applying for trademarks drops to about $23 \%$. One reason for this could be that the same trademark could protect more than one innovation, as trademarks are granted to firms and are not necessarily innovation specific.

Looking across groups of firms we find that in the CIS data small firms are more likely to trademark but when we look at innovation specific data there is no such difference. Instead consistent with the literature linking innovation and trademarking we find that firms that undertake regular $\mathrm{R} \& \mathrm{D}$, or report a valuable product innovations or a valuable new to market innovation were more likely to trademark Götsch and Hipp (2012). These same characteristics also drive patenting behavior.

[Table 3 here] 
In Table 4 we examine these differences in a multivariate context controlling for several other factors such as the industry affiliation of the firm (proxied by 17 industry dummies) ${ }^{2}$, its level of openness to external technology and the firm's reported levels of imitative competition.

We restrict our attention to SIPU innovators and estimate a probit model to explain the probability of trademark application, in order to protect the most valuable innovation. The results confirm all the descriptive findings of Table 3 with a few exceptions. We do not find a statistically significant impact of R\&D activities and new-to-market innovation, once we control for industry specific factors. This can probably be explained by the presence of the $R \& D$ variable: since in most cases doing $R \& D$ is a necessary precondition to be able to develop patentable brand new products, once we control for it the positive effect of new to the market innovation fades away. Also in this case firm size does not significantly affect trademark propensity.

Among the other control variables we also include some new variables not included in Table 3. We check for the effect of openness, i.e., the fact that a firm develops its most important innovation with other external partners, and we find that it exerts a negative effect on trademarking. When we further investigate the effect of openness we find that it is not the degree of openness (the number of different types of different external actors involved in the innovative process) that matters for the decision to trademark or not. Rather, we find that it is mainly the collaboration with clients that decreases the willingness of firms to use trademarks. This is in line with our theoretical reasoning, according to which collaboration with downstream clients might present issues with respect to intellectual property or also may pre-dispose innovators to rely on the distribution channels of their clients.

We also investigate a possible linkage between trademarking and patenting activity. We want to check if the firms that patent a large share of their new products are also more likely to apply for a trademark for their most valuable innovation. This may indicate a higher firm awareness about the use of intellectual property appropriability tools, as well as a general indication of the innovativeness of the company. In Table 4, the overall propensity to patent for the firms' innovation portfolio (available from UK CIS 2015) is positive and significant suggesting that innovators with larger patent portfolios are also more likely to apply for trademark protection for their most valuable innovation. The effect of patent portfolios on trademark propensity suggests that indeed a higher share of patented new products also increases the likelihood that a firm will apply for a trademark for their most valuable innovation.

[Table 4 here]

\section{Reasons why innovators do not apply for trademark protection}

\footnotetext{
2 The results are robust to the use of less fine-grained industry dummies (we also ran our models with only 7 macro-industry dummies), in order to avoid the risk of over-fitting of the model.
} 
An additional way by which we can understand the motives that lead innovators to not use trademarks is to ask to them to explain the reasons why. In SIPU, innovators were also asked for the reasons why they did not apply for a trademark for their most valuable innovation. The list of reasons for not using trademarks that respondents could choose included a) the innovation was already protected by existing trademarks, b) there was no danger of infringement, c) the firm uses distribution channels to market our product. In addition, there was a free form field where firms could enter other reasons not included on the list. We examined each of these additional reasons and classified them in the three additional groups: d) trademarks were not perceived as important by the firm, e) trademarks were not possible for the specific type of innovation, f) the innovation was not novel enough to be eligible for trademark use.

In order to analyse the reasons for not trademarking within a regression framework, we reclassify the reasons provided by the firms for not trademarking their innovation into three main categories:

(i) Trademark not necessary and alternative channels, which includes the following reasons b) no danger of infringement, c) use of alternative distribution channels and d) trademarks not considered important,

(ii) Trademark not possible, which includes the reasons e) trademark was not possible and f) non-novel innovation

(iii) Already existing trademarks: when a) the innovation was already covered by existing trademarks

In Figure 3 we show through a Venn diagram the distribution of these three main reasons and the overlapping of these reasons. The figure shows that by regrouping the reasons in such a way around half of the firms are classified in the category "trademark not necessary and alternative channels", while the other two categories "already existing trademark" and "trademark not possible " include $28 \%$ and $17 \%$ respectively of SIPU innovators (who did not use trademarks). The limited overlap between these reasons suggests that they are not complementary reasons.

[Figure 3 here]

Due to the limited overlap across reasons, we estimate three separate probit models to account for the possible factors that might influence the selection of each one of the three reasons for not applying for trademark for the innovation.

$$
y_{i}^{S}=a_{0}+a_{1} I N N_{-} T Y P E+a_{2} O P E N+a_{2}^{\prime} X+u_{i}
$$

Where $y$ stands for a set of $s$ dummy variables $(0 / 1)$ that denote whether the firm indicated a specific reason to explain the choice of not applying for a trademark for its most relevant innovation. 
We include a number of independent variables that we believe might explain the reasons for not trademarking: INN_TYPE indicate the specific type of innovation (product, process or business strategy; OPEN, which indicates whether the firm engaged in collaborative open innovation for the development of the specific innovation, since we believe that especially interaction with customers might be correlated with the use of channels that are alternative to trademarks. Finally X stands for other innovation-specific and firm-specific factors that are likely to be correlated with the reason chosen by the firm for not using trademarks. The innovation-specific factors include the degree of novelty of the innovation, the value of the innovation and the presence of financing that is external to the firm (grants, policy programmes, venture capital, etc). The firm level variables include firm size, the presence of investments in Research and Development, the overall patent propensity and the industry affiliation. We run our probit analyses on 196 firm-innovation observations, that is the number of innovators in SIPU2015 who have not applied for a trademark for their most valuable innovation. ${ }^{3}$

\section{Results}

In Table 5 we present some data about the frequency of each of these different reasons for different groups of firms. The most common reason for not applying for a trademark is the presence of a pre-existing trademark (27\% of cases), followed by no danger of infringement (24\%). Respectively $21 \%$ and $15 \%$ of the firms reported that trademarks were not important or that they were not possible for the specific innovation introduced. $11 \%$ percent of firms, instead, reported that they used alternative distribution channels and, hence, did not need to trademark their innovations.

[Table 5 here]

Overall, the results highlight the fact that there is not a one-to-one correspondence between innovations and trademarks; firms might introduce new products and still use (extend) their old trademarks to also cover the new product. The second finding is that a number of innovators do not perceive trademarks to be a very effective way to protect their innovations, since they do not believe that there is significant danger of infringement, or they generally do not consider them as relevant tools for appropriating value (such as when innovation involved bespoke work). In some cases, then, the specific nature of the innovation did not allow for trademark application.

When looking at the impact of size on the different reasons indicated by firms who did not use trademarks, we find that small firms are generally more likely to say that trademarks were not important, while large firms are more likely to say that trademarks were not possible due to the specific nature of the innovation. This suggests that while large firms are more aware of which kind of products can be protected by trademarks and which cannot, small firms tend

\footnotetext{
${ }^{3}$ For 18 firms who innovate and did not apply for a trademark we could not perform our probit analyses. This is because some firms indicated different reasons for the decision not to apply for trademark (not included in our three categories), while a few firms did not answer to all of the questions of the survey, resulting in some missing values among our covariates.
} 
to underestimate the value of trademark protection, possibly also because of lower awareness of how to use them.

Among firms that collaborate with external partners (open innovators) we find that they are more likely to consider trademarks as not important (due to the bespoke nature of the work) and because open firms reported use of other distribution channels to market their products.

In Table 6 we report three probit estimates that explain the probability to indicate each of the three reasons identified above as relevant for the decision not to apply for a trademark for the most relevant innovation. These are: a) Trademark not necessary and alternative channels b) Trademark not possible c) Already existing trademarks. Looking at the results, all of which control for industry specific factors, we find that few of the factors related to firm or innovation-specific features are able to explain the different reasons indicated by the respondents. Research and Development, and overall patent propensity are not significant, as well as the type of innovation (product, process or business strategy) and the degree of novelty of the innovation. Firms that obtained external financing were more likely to have an existing trademark, which probably worked as a quality signal also for the financiers.

[Table 6 here]

In line with the results in Table 5 we find instead that adopting an open strategy for innovation increases the likelihood that trademarks were deemed not necessary or that alternative channels had been used. More specifically we find that when clients are involved the likelihood of using other channels to market the innovation increases. This is in line with our expectations about the involvement of clients in the collaborative process: having them collaborate in innovation also increases the likelihood of using the clients' distribution channels for the marketing of the innovation. On the contrary we find that open innovation and collaboration with clients is negatively related with the fact that trademark was not possible, confirming that it is not the nature of the innovation per se that prevents firms from trademarking when open innovation is at stake, but rather the fact that firms choose alternative channels when they collaborate with other actors (and especially with customers). The results in column (3) instead show that the value of the innovation is positively correlated with the decision to use an already existing trademark for the protection of the new product. This speaks in favour of the fact that especially when an innovation is valuable firms may resort to the use of already existing trademark rather than introducing a new one just for the specific innovation.

\section{Summary and implications}

In the marketing literature, trademark application is often seen as a precursor to branding, but in recent years trademark applications have attracted the attention of several scholars of technology management as a distinct IP strategy for innovators. Many empirical studies have found trademark applications to be associated with innovation (Mendonca et al., 2004, Flikkema et al., 2014; Block et al., 2015) and that innovative companies tend to trademark more than non-innovative ones.

Despite exclusivity advantages and the comparatively low costs of trademark filing, only about half of all start-ups in technology sectors actually file trademarks. In this paper, we ask 
why more innovators do not file for trademarks, even though they are so cheap to obtain? We investigate this question using a novel survey that obtains innovation specific data about the reasons for not trademarking and is built to link into the CIS. This data structure enables us to simultaneously look at innovation specific and firm specific characteristics of innovations that make particular reasons for not trademarking more likely than others.

The theoretical literature sees trademarks as essentially solving an information asymmetry problem between the firm and its customers. For innovative firms, this may be information about the quality of their products and services, (Block et al., 2014) or in the case of new innovators, trademarks can flag the market introduction of completely new products and services (Flikkema et al., 2014). Brands may also convey this information readily to customers for all products of a firm. New and existing innovators may also depend upon distributors and agents to reach the product and the information about the product to consumers. In both of these cases, firms would not need to trademark because the information problem is being sorted out using other means viz. brands, distribution channels. Where a firm has a trademark, the trademark may cover several types of goods supplied by the firm. Our results broadly support these arguments as important ones for not trademarking an innovation.

Service firms are heavy users of trademarks to protect their innovations which are often collaborative and not patentable. The literature on collaborative (open) innovation has highlighted the challenge that collaborative innovation may pose for the enforcement of formal IP rights. The discussion on this issue has tended to focus disproportionately on patents strategy with regard to patenting but our results suggest that open firms are less likely to apply for trademarks and those collaborating with clients are more likely to cite having alternative channels or agreements that prevent a trademark application from being made.

Thus, our empirical analysis finds that while there is an undeniable linkage between innovations and trademarking this is not a one-to-one relationship. Fewer innovations of value are trademarked than patented. Even though innovative products may be associated with higher information asymmetry than other kinds of goods, existing trademarks, alternative distribution channels and pre-existing agreements may protect a firm without having to take recourse to trademark applications.

Our analysis is not free of important limitations that should be taken into account when interpreting our results. First our empirical methodology is not able to identify clear causal relationships, so our results should be interpreted rather as an indication that specific firmlevel or innovation-specific factors are associated (or not) with the decision to apply for a trademark, as well as to the specific reasons behind the decision not to apply for it. Secondly, while we believe that the focus on "significant innovations" represents an important novelty and adds to the overall contribution of our study, it is also important to acknowledge that the generalizability of the results is limited to this specific type of innovation. In other words it could be for example that trademarks are especially important for innovations that are less relevant or central in the innovation portfolio of a company. If that is the case our results should be interpreted keeping this into account. Lastly our results provide very detailed information about the reasons why firms do not apply for trademarks, but they do not provide the same level of detail about the reasons why firms instead use them. From our empirical 
analysis about the propensity to apply for a trademark we can identify the main factors that are associated with this decision, which provide a hint of which are types of innovations and the firm-level factors that are generally associated with the decision to apply for trademarks, but do not know the explicit motives behind it. This leaves room for future survey-based empirical studies who might explicitly ask firms who apply for trademarks the reasons behind it.

Despite these important limitations, this study allows us to draw some useful policy implications. Recent years have witnessed an increased interest in the analysis of trademarks as a possible indicator of firms' innovation, as opposed to other traditional indicators such as patents or innovation surveys. Typically this can lead to policies aimed at boosting the use of trademarks by firms, both because this would also mean that firms are more innovative, and because it may provide more incentives to firms' innovation, by increasing the appropriability of their innovation efforts. Our analysis shows that many innovating firms may decide not to trademark even very valuable innovations simply because they are not needed and a variety of scenarios correspond to this - for example, because of collaborative innovation with users gives innovators access to client distribution channels, because of the existence of previously established distribution channels, or because pre-existing trademarks covering also the new products. These specific cases may undermine the effectiveness of policies aimed at increasing trademark applications.

\section{References}

Allegrezza, S. and Guarda-Rauchs, A. (1999). The determinants of trademarks deposits: An econometric investigation (A case study of the Benelux). Economie Appliquée 52(2), pp. 5168.

Amara, N., Landry, R. and Traoré, N. (2008). Managing the protection of innovations in knowledge-intensive business services. Research Policy 37, pp. 1530-1547.

Ashish Arora, Suma Athreye and Can Huang (2016) The paradox of openness revisited. Research Policy, Vol. 45(7): 1352-1361.

Bhandari, B. (2005). The Ranbaxy story: the rise of an Indian multinational, Penguin Global.

Block, . H.,De Vries, G., Schumann J.H., Sandner, P. (2014) Trademarks and venture capital valuation, Journal of Business Venturing, 29(4): 525-542.

Castaldi, C. (2018) To trademark or not to trademark: The case of the creative and cultural industries. Research Policy, 47 (2018) 606-616.

Desyllas, P, Miozzo, MM, Lee, HF \& Miles, I (2018), 'Capturing value from innovation in knowledge-intensive service firms: the role of competitive strategy' British Journal of Management 29 (4): 769-795.

Flikkema, M.J., de Man, A.P., Castaldi, C., 2014. Are trademark counts a valid indicator of innovation? Results of an in-depth study of new benelux trademarks filed by SMEs. Industry and Innovation 21 (4), 310-331 
Flikkema, M.J., Castaldi, C., De Man, A-P., Seip, M. (2017) Explaining the TrademarkInnovation Linkage: the Role of Patents and Trademark Filing Strategies, mimeo.

Fosfuri and Girratana (2009)

Götsch, M. and Hipp, C. (2012). Measurement of innovation activities in the knowledge intensive services industry: a trademark approach. The Service Industries Journal, 32(13), pp. 2167-2184.

Greenhalgh, C. and M. Rogers (2012). Trade Marks and Performance in Services and Manufacturing Firms: Evidence of Schumpeterian Competition through Innovation. Australian Economic Review, 45 (1): 50-76.

He, X., Brouthers, K.D. \& Filatotchev, I. (2018). Market Orientation and Export Performance: The Moderation of Channel and Institutional Distance. International Marketing Review 35(2): 258-279.

Helmers, C. and Rogers, M., (2011) Does patenting help high-tech start-ups?, Research Policy, 40(7), 1016-1027

Hipp, C., Grupp, H., 2005. Innovation in the service sector: the demand for service-specific innovation measurement concepts and typologies. Research Policy 34, 517-535

Jensen, P. H. and Webster, E. (2009). Another look at the relationship between innovation proxies. Australian Economic Papers, 48(3), pp. 252-269.

Landes, W. and Posner, R., (1987) Trademark Law: An Economic Perspective, Journal of Law and Economics, 30, 2, 265-309

Laursen, K. and Salter, A. J.. 2014. The paradox of openness: Appropriability, external search and collaboration. Research Policy 43 (5): 867-878.

Mendonça S., Pereira, T.S. and Godinho, M.M. (2004). Trademarks as an indicator of innovation and industrial change. Research Policy, 33, 1385-1404.

Miozzo, M. P. Desyllas, H. Lee, I. Miles (2016). Innovation collaboration and appropriability by knowledge-intensive business services firms. Research Policy, 45 (7): 1337-1351.

Ramello, G. B. and Silva, F. (2006). Appropriating Signs and Meaning: The Elusive Economics of Trademark. Industrial and Corporate Change, 15: 937-963.

Rogers, M., Greenhalgh, C. and Helmers, C. (2007) The association between the use of IP by UK SMEs in 2001 and subsequent performance in 2002 to 2004, mimeo.

Schmoch, U. (2003). Service marks as novel innovation indicator. Research Evaluation, 12, 149-156.

Thomä, J., Bizer, K., 2013. To protect or not to protect? Modes of appropriability in the small enterprise sector. Research Policy 42 (1), 35-49

WIPO (2013). World Intellectual Property Report 2013 - Brands - Reputation and Image in the Global Marketplace. 
Figures and Tables 
Figure 1: Size distribution of firms in the SIPU 2015 sample compared to CIS 2015

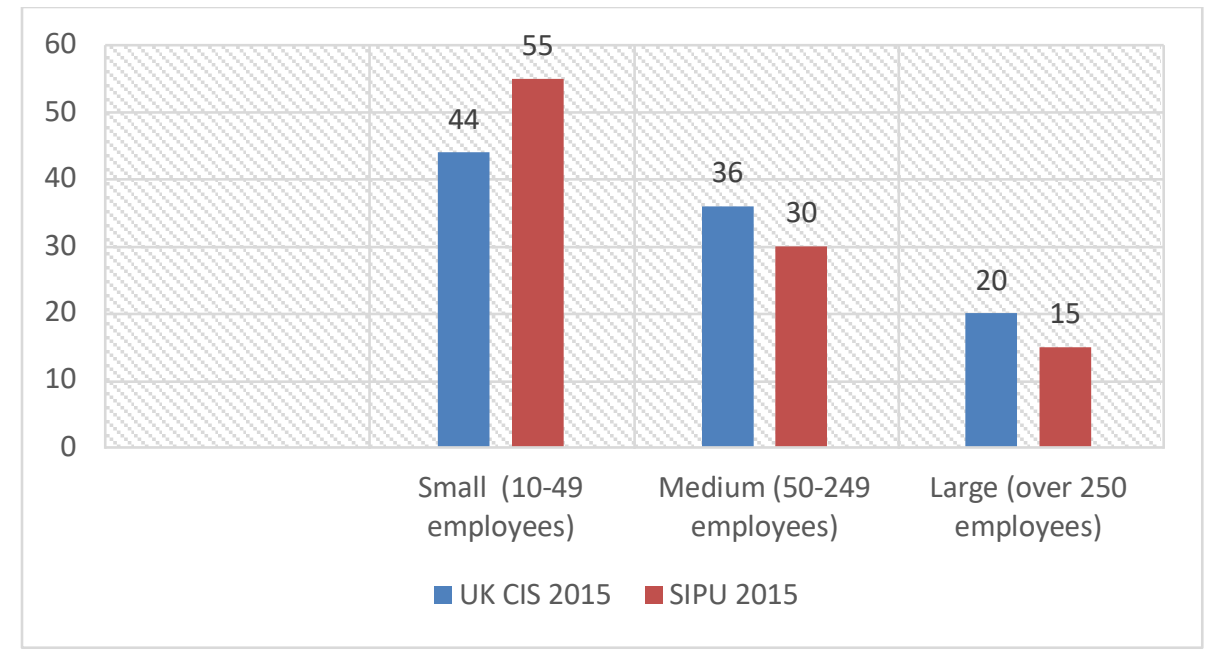

Figure 2: Distribution of innovators in SIPU and CIS

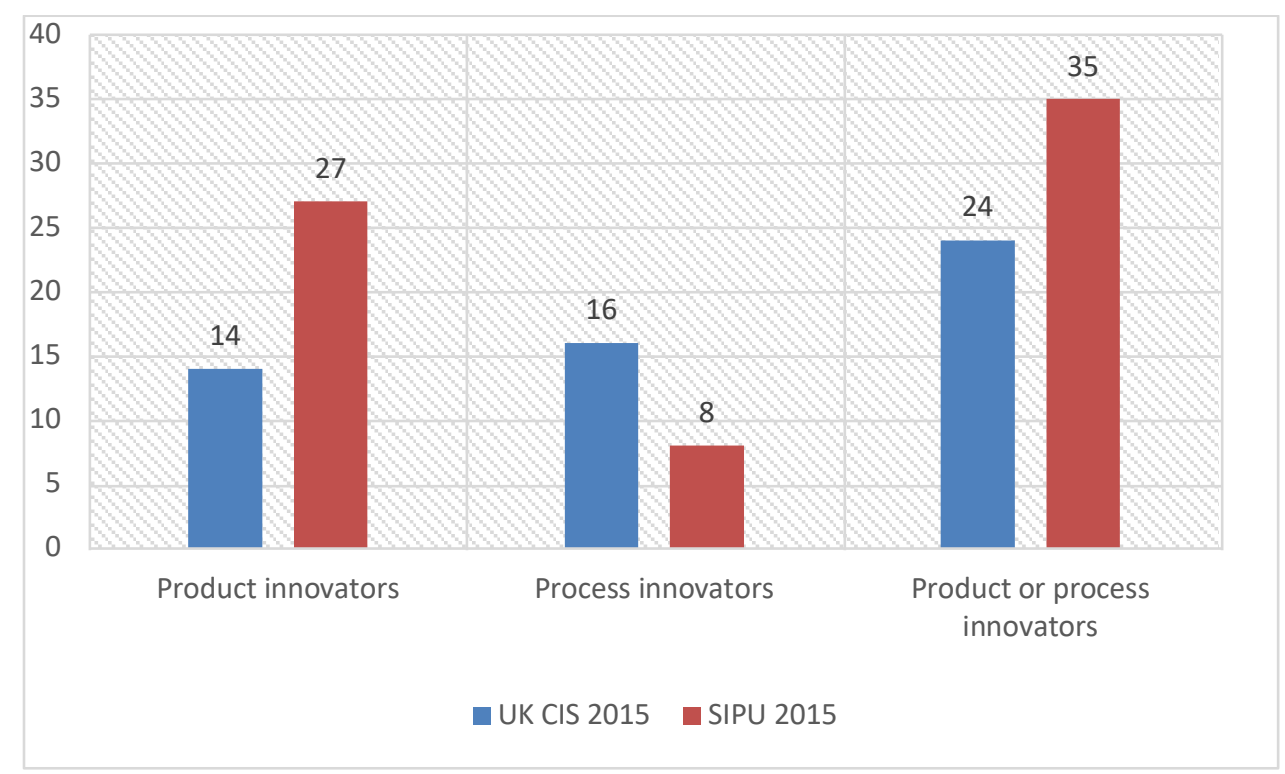


Figure 3: Venn diagram of reasons for not filing for trademark.

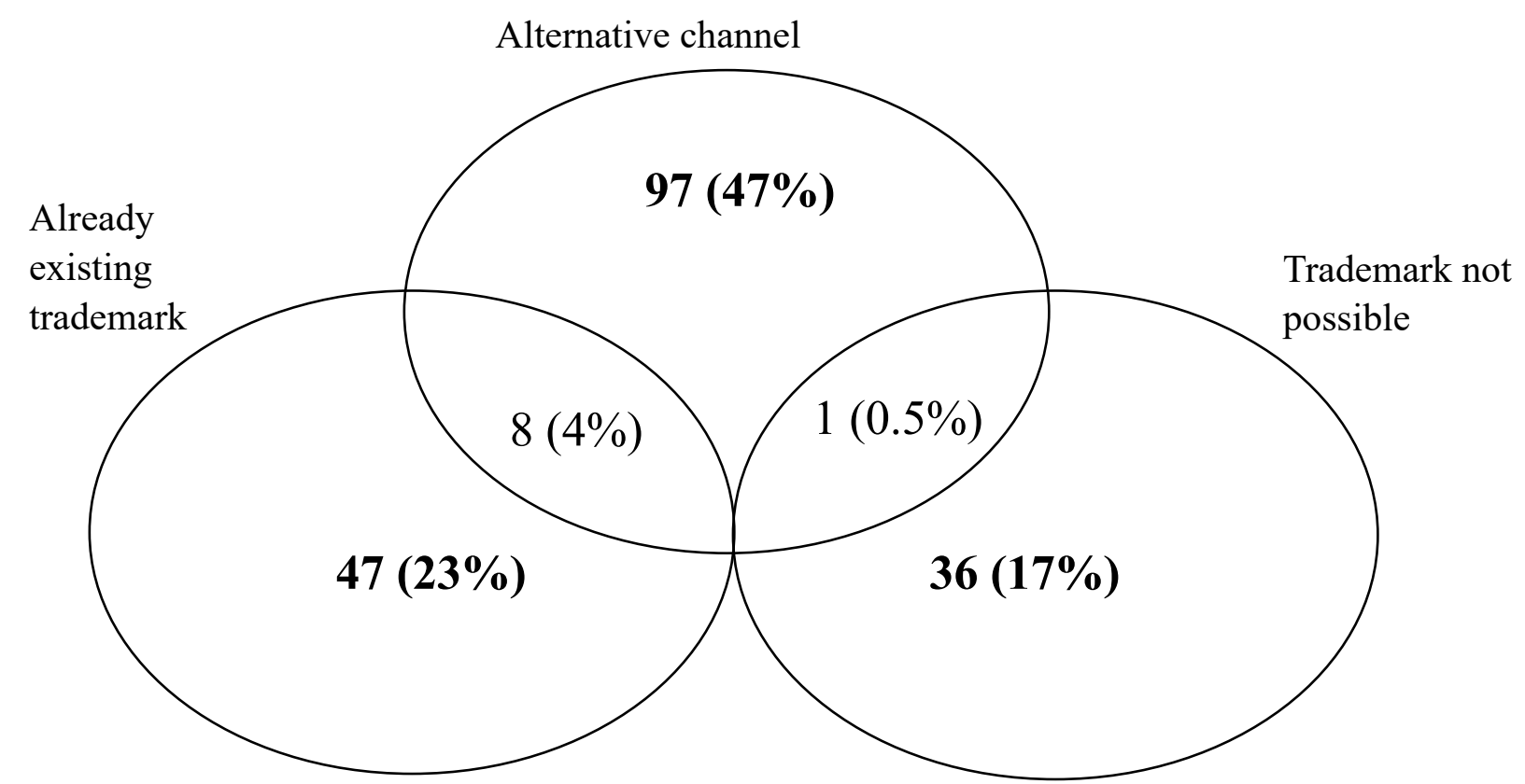

Note: $\mathrm{N}=203(100 \%)$; in 14 cases $(7 \%)$ none of the three reasons was specified as important (other reasons were specified as important). 
Table 1: Sectoral distribution of sample in CIS and SIPU

\begin{tabular}{|c|c|c|c|c|}
\hline Industry sector & CIS & $\begin{array}{c}\% \text { of } \\
\text { sample }\end{array}$ & SIPU & $\begin{array}{l}\% \text { of } \\
\text { sample }\end{array}$ \\
\hline 05-09: Mining and Quarrying & 137 & 0.91 & 3 & 0.47 \\
\hline 10-18: Manufacture of food, clothing and wood & 682 & 4.52 & 22 & 3.47 \\
\hline 19-25: Manufacture of fuels, chemicals and plastics & 755 & 5.00 & 40 & 6.31 \\
\hline 26-28: Manufacture of electrical \& optical equips & 478 & 3.17 & 25 & 3.94 \\
\hline 29-30: Manufacture of transport equipment & 262 & 1.74 & 10 & 1.58 \\
\hline 31-33: Manufacture not elsewhere classified & 280 & 1.86 & 19 & 3.00 \\
\hline 35-39: Electricity, gas and water supply & 232 & 1.54 & 8 & 1.26 \\
\hline 41-43: Construction & 740 & 4.90 & 23 & 3.63 \\
\hline 45-46: Wholesale trade (including cars and bikes) & 4,214 & 27.92 & 163 & 25.71 \\
\hline 47: Retail Trade (excluding cars and bikes) & 460 & 3.05 & 13 & 2.05 \\
\hline 49-52: Transport & 592 & 3.92 & 20 & 3.15 \\
\hline 53: Post and courier activities & 120 & 0.80 & 4 & 0.63 \\
\hline 55-56: Hotels \& restaurants & 684 & 4.53 & 28 & 4.42 \\
\hline 58, 62, 63: Computer and related activities & 449 & 2.98 & 26 & 4.10 \\
\hline 59-60: Motion picture, video and TV programmes & 126 & 0.83 & 11 & 1.74 \\
\hline 61: Telecommunications & 166 & 1.10 & 9 & 1.42 \\
\hline 64-66: Financial intermediation & 668 & 4.43 & 22 & 3.47 \\
\hline 68: Real estate activities & 361 & 2.39 & 8 & 1.26 \\
\hline 69,70,75,76,78-83: Other services nec & 2,208 & 14.63 & 102 & 16.09 \\
\hline 71.1: Architectural \& engineering activities & 421 & 2.79 & & 0.00 \\
\hline 71.2: Clinical testing and analysis & 113 & 0.75 & 25 & 3.94 \\
\hline 72: Research and experimental development & 399 & 2.64 & 37 & 5.84 \\
\hline 73: Advertising and market research & 186 & 1.23 & 4 & 0.63 \\
\hline 74: Other professional, scientific activities & 146 & 0.97 & 6 & 0.95 \\
\hline 77: Renting of machinery and equipment & 212 & 1.40 & 6 & 0.95 \\
\hline
\end{tabular}

Based on SIC 2007 codes 
Table 2: Dependent and independent variables created

A. Dependent variables

\begin{tabular}{|l|l|l|}
\hline Variable & Source of Data & Description of the variable \\
\hline Trademark application (Table 4) & SIPU 2015 & $\begin{array}{l}\text { Dummy variable =1 when respondent reports applying for a trademark to protect their most } \\
\text { valuable innovation }\end{array}$ \\
\hline Trademark not necessary (Table 6) & SIPU 2015 & $\begin{array}{l}\text { Dummy variable=1, if firm said any of the following reasons prevented them from applying } \\
\text { for a trademark- a) trademarks not considered important, b) no danger of infringement and c) } \\
\text { use of alternative distribution channels }\end{array}$ \\
\hline Trademark not possible (Table 6) & SIPU 2015 & $\begin{array}{l}\text { Dummy variable=1, if firm said any of the following reasons prevented them from applying } \\
\text { for a trademark- a) trademark was not possible and b) non-novel innovation }\end{array}$ \\
\hline Existing trademarks (Table 6) & SIPU 2015 & $\begin{array}{l}\text { Dummy variable=1, if firm said its reason for not seeking a trademark was because the } \\
\text { innovation was already covered by existing trademarks }\end{array}$ \\
\hline
\end{tabular}

\section{B. Associated characteristics}

\begin{tabular}{|l|l|l|}
\hline Firm specific variables & Source of Data & Description of the variable \\
\hline Small firm & CIS 2015 & Dummy variable $=1$, if the firm employed less than 50 persons \\
\hline Medium firm & CIS 2015 & Dummy variable $=1$, if the firm employed between 50 and 249 employees \\
\hline Large firm & CIS 2015 & Dummy variable $=1$, if the firm employed more than 250 employees \\
\hline Continuous R\&D & CIS 2015 & Dummy variable that takes value 1 if firms had undertaken internal R\&D in 2012, 2013 \& 2014 \\
\hline Overall patent propensity & CIS 2015 & The proportion of innovations between 2012-2014 that was protected by patents \\
\hline 17 Industrial sectors & CIS 2015 & $\begin{array}{l}\text { Based on the 2-digit SIC and aggregated to get a minimum of 20 observations per group. See } \\
\text { Table A1 for details }\end{array}$ \\
\hline Innovation specific variables (for the commercially & most valuable innovation) \\
\hline Openness & SIPU 2015 & $\begin{array}{l}\text { Dummy variable }=1 \text { when respondent reports collaborative partner was involved in producing } \\
\text { its most valuable innovation }\end{array}$ \\
\hline Suppliers & $\begin{array}{l}\text { Dummy variable }=1 \text { when respondent reports collaboration with supplier was involved in } \\
\text { producing its most valuable innovation }\end{array}$ \\
\hline Clients & $\begin{array}{l}\text { Dummy variable }=1 \text { when respondent reports collaboration with client was involved in } \\
\text { producing its most valuable innovation }\end{array}$ \\
\hline
\end{tabular}




\begin{tabular}{|l|l|l|}
\hline Other types of collaboration & SIPU 2015 & $\begin{array}{l}\text { Dummy variable }=1 \text { when respondent reports collaboration with public sector labs, consultants, } \\
\text { competitors or HEI was involved in producing its most valuable innovation }\end{array}$ \\
\hline Value of innovation & SIPU 2015 & Value of turnover (\%) in 2014 accounted for by the most valuable innovation \\
\hline Product innovation & SIPU 2015 & Dummy variable $=1$, if the most valuable innovation was a product innovation \\
\hline Process innovation & SIPU 2015 & Dummy variable $=1$, if the most valuable innovation was a process innovation \\
\hline Business strategy innovation & SIPU 2015 & Dummy variable $=1$, if the most valuable innovation was a wider innovation \\
\hline New to the market innovation & SIPU 2015 & Dummy variable $=1$, if the most valuable innovation was a new to the market \\
\hline New to the firm innovation & SIPU 2015 & Dummy variable $=1$, if the most valuable innovation was new to the firm \\
\hline Any external finance & & $\begin{array}{l}\text { Dummy variable }=1, \text { if the firm used any external finance to finance its most valuable } \\
\text { innovation }\end{array}$ \\
\hline
\end{tabular}


Table 3: Frequency of innovators applying for trademarks and patents in the CIS9 and in SIPU for their most valuable innovation

\begin{tabular}{|c|c|c|c|c|c|c|c|c|c|c|c|c|}
\hline & \multicolumn{3}{|c|}{$\begin{array}{c}\text { Trademarks all } \\
\text { CIS innovators } \\
\text { (1) }\end{array}$} & \multicolumn{2}{|c|}{$\begin{array}{c}\text { Trademarks } \\
\text { SIPU } \\
(2)\end{array}$} & & \multicolumn{2}{|c|}{$\begin{array}{c}\text { Patents all CIS } \\
\text { innovators } \\
(3) \\
\end{array}$} & & \multicolumn{2}{|c|}{$\begin{array}{c}\text { Patents SIPU } \\
(4) \\
\end{array}$} & \\
\hline & Num. & $\%$ & & Num. & $\%$ & & Num. & $\%$ & & Num. & $\%$ & \\
\hline Total Innovating firms & 2578 & & & 277 & & & 2641 & & & 277 & & \\
\hline Total firms using trademarks/patents & 761 & 29.52 & & 63 & 22.7 & & 666 & 25.22 & & 71 & 25.63 & \\
\hline Small firms (<49 employees) & 248 & 25.1 & $* * *$ & 33 & 23.4 & & 197 & 19.58 & $* * *$ & 35 & 24.8 & \\
\hline Medium firms (50-249 employees) & 326 & 30.96 & & 22 & 23.9 & & 285 & 26.46 & $* * *$ & 25 & 27.2 & \\
\hline Large Firms ( $>250$ employees) & 187 & 34.82 & & 8 & 18.2 & & 184 & 32.97 & $* * *$ & 11 & 25 & \\
\hline Product innovation & 584 & 38.8 & $* * *$ & 50 & 29.1 & $* * *$ & 546 & 35.23 & $* * *$ & 57 & 33.1 & $* *$ \\
\hline Process innovation & 454 & 25.65 & & 6 & 11.3 & & 381 & 21.04 & & 10 & 18.9 & \\
\hline New to Market & 379 & 43.87 & $* * *$ & 37 & 27.4 & $* *$ & 397 & 43.77 & $* * *$ & 44 & 32.5 & $* *$ \\
\hline New to Firm & 436 & 31.43 & & 9 & 12.8 & & 328 & 23.4 & & 10 & 14.3 & \\
\hline Continuous R\&D & 438 & 38.9 & $* * *$ & 41 & 29.1 & $* * *$ & 451 & 38.06 & $* * *$ & 49 & 34.75 & $* * *$ \\
\hline No R\&D or discontinuous R\&D & 323 & 22.25 & & 22 & 16.2 & & 215 & 14.77 & & 22 & 16.18 & \\
\hline Independent firms & - & - & & 35 & 24 & & & & & 30 & 20.6 & \\
\hline Affiliated to a group & - & - & & 28 & 21.4 & & & & & 41 & 31.3 & $* *$ \\
\hline Internally financed & - & - & & 47 & 22.6 & & & & & 46 & 22.1 & \\
\hline Any external finance & - & - & & 14 & 24.5 & & & & & 23 & 40.4 & $* * *$ \\
\hline
\end{tabular}

Source: Computations from UK CIS 2015 and SIPU 2015. Notes: ** for significance at 5\%; *** for significance at $1 \%$. 


\section{Innovation specific variables}

Reference product innovation

Process innovation

$$
\begin{gathered}
-0.142 * * * \\
(0.051) \\
-0.076 \\
(0.068) \\
0.063
\end{gathered}
$$$$
-0.122 * *
$$$$
-0.15 * * *
$$$$
\text { (0.056) }
$$

Business strategy

$-0.059$

$-0.095$

$(0.074)$

New to the market innovation$$
0.048
$$$$
0.072
$$

(0.055)

$(0.053)$

$\begin{array}{lc}\text { Openness measures } & -0.121^{* *} \\ \text { Openness (dummy) } & (0.053)\end{array}$

Level of openness

0.108

(0.151)

Suppliers

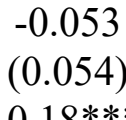

Clients

$$
(0.047)
$$

Other types of collaborations

Value of invention

$\begin{array}{ccc}0.014 & 0.012 & 0.014 \\ (0.017) & (0.017) & (0.016) \\ -0.003 & -0.018 & -0.011 \\ (0.063) & (0.063) & (0.065)\end{array}$

Firm specific variables

Small firm (<49 employees)

$\begin{array}{ccc}0.020 & 0.007 & 0.033 \\ (0.057) & (0.058) & (0.057) \\ 0.057 & 0.057 & 0.053 \\ (0.057) & (0.058) & (0.058) \\ 0.183 * * & 0.191 * * & 0.168^{*} \\ (0.084) & (0.086) & (0.086)\end{array}$

Reference no competition

Competitors 1 to 5

$\begin{array}{ccc}-0.028 & -0.030 & -0.025 \\ (0.057) & (0.057) & (0.056) \\ 0.086 & 0.096 & 0.069 \\ (0.098) & (0.094) & (0.097)\end{array}$

Competitors more than 5

$$
\begin{gathered}
0.086 \\
(0.098)
\end{gathered}
$$$$
0.096
$$$$
(0.097)
$$

17 industry dummies

Observations yes

Pseudo R-squared

277

yes

0.142

277

yes

Log-likelihood

$-127.4$

0.127

0.157

Note: The coefficients reports the marginal effects from probit estimations. Robust standard errors in parentheses, $* * * \mathrm{p}<0.01, * * \mathrm{p}<0.05, * \mathrm{p}<0.1$ 
Table 5: Reasons for forgoing trademark protection given by innovating firms (\% of firms choosing each reason)

\begin{tabular}{|c|c|c|c|c|c|c|c|c|c|c|c|}
\hline Reasons for no trademark & $\begin{array}{l}\text { No Trad } \\
\text { firms }(\mathrm{n}\end{array}$ & hark & $\begin{array}{l}\text { Small } \\
\text { firms }\end{array}$ & $\begin{array}{l}\text { Medium } \\
\text { Firms }\end{array}$ & $\begin{array}{l}\text { Large } \\
\text { firms }\end{array}$ & $\begin{array}{l}\text { Product } \\
\text { innovators }\end{array}$ & $\begin{array}{l}\text { Process } \\
\text { innovato } \\
\text { rs }\end{array}$ & $\begin{array}{l}\text { No } \\
\text { continuous } \\
\text { R\&D } \\
\end{array}$ & $\begin{array}{l}\text { Continu } \\
\text { ous } \\
\text { R\&D }\end{array}$ & $\begin{array}{l}\text { Not } \\
\text { Open }\end{array}$ & Open \\
\hline Already existing trademark & 55 & 27.1 & 29.2 & 25.4 & 23.3 & 25.2 & 25.5 & 28.4 & 25.5 & 25.7 & 27.8 \\
\hline No danger of infringement & 49 & 24.1 & 20.8 & 28.4 & 26.7 & 24.3 & 31.9 & 18.3 & 30.9 & 28.6 & 21.8 \\
\hline $\begin{array}{l}\text { Trademark not perceived } \\
\text { important }\end{array}$ & 44 & 21.7 & 25.5 & 17.9 & 16.7 & 20.0 & 21.3 & 25.7 & 17.0 & 14.3 & 25.6 \\
\hline Trademark not possible & 32 & 15.8 & 11.3 & 17.9 & 26.7 & 19.1 & 10.6 & 14.7 & 17.0 & 24.3 & 11.3 \\
\hline $\begin{array}{l}\text { Distribution channel to } \\
\text { market product }\end{array}$ & 24 & 11.8 & 12.3 & 13.4 & 6.7 & 13.9 & 6.4 & 11.0 & 12.8 & 4.3 & 15.8 \\
\hline Innovation without novelty & 5 & 2.5 & 3.8 & 1.5 & 0.0 & 0.9 & 6.4 & 3.7 & 1.1 & 4.3 & 1.5 \\
\hline Other reasons & 14 & 6.9 & 6.6 & 8.9 & 3.3 & 8.6 & 4.2 & 7.3 & 6.4 & 5.7 & 7.5 \\
\hline
\end{tabular}

Source: SIPU2015. Notes: Values in bold identify statistically significant differences. 
Not necessary and VARIABLES alternative channels
Trademark not possible
Existing trademark

\begin{tabular}{|c|c|c|c|c|c|c|}
\hline \multicolumn{7}{|l|}{ Innovation specific variables } \\
\hline \multicolumn{7}{|l|}{ Reference product innovation } \\
\hline Process innovation & $\begin{array}{c}0.040 \\
(0.098)\end{array}$ & $\begin{array}{c}0.057 \\
(0.098)\end{array}$ & $\begin{array}{l}-0.009 \\
(0.023)\end{array}$ & $\begin{array}{l}-0.011 \\
(0.022)\end{array}$ & $\begin{array}{l}-0.011 \\
(0.082)\end{array}$ & $\begin{array}{l}-0.024 \\
(0.079)\end{array}$ \\
\hline Business strategy & $\begin{array}{c}0.002 \\
(0.113)\end{array}$ & $\begin{array}{c}0.012 \\
(0.115)\end{array}$ & $\begin{array}{l}-0.027 \\
(0.020)\end{array}$ & $\begin{array}{l}-0.027 \\
(0.020)\end{array}$ & $\begin{array}{c}0.102 \\
(0.104)\end{array}$ & $\begin{array}{c}0.065 \\
(0.102)\end{array}$ \\
\hline New to the market innovation & $\begin{array}{l}-0.095 \\
(0.080)\end{array}$ & $\begin{array}{l}-0.109 \\
(0.080)\end{array}$ & $\begin{array}{c}0.014 \\
(0.022)\end{array}$ & $\begin{array}{c}0.014 \\
(0.022)\end{array}$ & $\begin{array}{l}-0.069 \\
(0.067)\end{array}$ & $\begin{array}{l}-0.048 \\
(0.066)\end{array}$ \\
\hline \multicolumn{7}{|l|}{ Openness measures } \\
\hline Openness (dummy) & $\begin{array}{l}0.152^{*} \\
(0.079)\end{array}$ & & $\begin{array}{l}-0.065^{*} \\
(0.034)\end{array}$ & & $\begin{array}{c}0.028 \\
(0.067)\end{array}$ & \\
\hline Suppliers & & $\begin{array}{c}0.057 \\
(0.099)\end{array}$ & & $\begin{array}{l}-0.036 * \\
(0.019)\end{array}$ & & $\begin{array}{c}0.123 \\
(0.092)\end{array}$ \\
\hline Clients & & $\begin{array}{l}0.208^{* *} \\
(0.096)\end{array}$ & & $\begin{array}{c}-0.039 * * \\
(0.020)\end{array}$ & & $\begin{array}{l}-0.103 \\
(0.079)\end{array}$ \\
\hline Other types of collaborations & & $\begin{array}{c}0.219^{* *} \\
(0.110)\end{array}$ & & $\begin{array}{c}-0.046^{* * *} \\
(0.017)\end{array}$ & & $\begin{array}{c}0.057 \\
(0.111)\end{array}$ \\
\hline Value of invention & $\begin{array}{l}-0.004 \\
(0.024)\end{array}$ & $\begin{array}{l}-0.010 \\
(0.024)\end{array}$ & $\begin{array}{c}0.001 \\
(0.006)\end{array}$ & $\begin{array}{c}0.001 \\
(0.006)\end{array}$ & $\begin{array}{c}0.030 \\
(0.021)\end{array}$ & $\begin{array}{l}0.036^{*} \\
(0.021)\end{array}$ \\
\hline Any external finance & $\begin{array}{l}-0.171 * \\
(0.096)\end{array}$ & $\begin{array}{l}-0.178^{*} \\
(0.097)\end{array}$ & $\begin{array}{c}0.003 \\
(0.027)\end{array}$ & $\begin{array}{c}0.004 \\
(0.028)\end{array}$ & $\begin{array}{c}0.249 * * * \\
(0.096)\end{array}$ & $\begin{array}{c}0.240^{* *} \\
(0.094)\end{array}$ \\
\hline \multicolumn{7}{|l|}{ Firm specific variables } \\
\hline Small firm ( $<49$ employees) & $\begin{array}{c}0.065 \\
(0.090)\end{array}$ & $\begin{array}{c}0.058 \\
(0.091)\end{array}$ & $\begin{array}{l}-0.025 \\
(0.025)\end{array}$ & $\begin{array}{l}-0.023 \\
(0.026)\end{array}$ & $\begin{array}{l}-0.020 \\
(0.079)\end{array}$ & $\begin{array}{l}-0.013 \\
(0.079)\end{array}$ \\
\hline Continuous R\&D & $\begin{array}{c}0.048 \\
(0.086)\end{array}$ & $\begin{array}{c}0.056 \\
(0.086)\end{array}$ & $\begin{array}{l}-0.006 \\
(0.024)\end{array}$ & $\begin{array}{l}-0.006 \\
(0.024)\end{array}$ & $\begin{array}{c}0.010 \\
(0.074)\end{array}$ & $\begin{array}{c}0.007 \\
(0.074)\end{array}$ \\
\hline $\begin{array}{l}\text { Overall patent propensity } \\
17 \text { industry dummies }\end{array}$ & $\begin{array}{c}0.068 \\
(0.151) \\
\text { YES } \\
\end{array}$ & $\begin{array}{c}0.086 \\
(0.153) \\
\text { YES } \\
\end{array}$ & $\begin{array}{c}-0.012 \\
(0.039) \\
\text { YES } \\
\end{array}$ & $\begin{array}{c}-0.014 \\
(0.039) \\
\text { YES } \\
\end{array}$ & $\begin{array}{c}-0.002 \\
(0.129) \\
\text { YES } \\
\end{array}$ & $\begin{array}{c}-0.003 \\
(0.132) \\
\text { YES }\end{array}$ \\
\hline Observations & 196 & 196 & 198 & 198 & 196 & 196 \\
\hline Pseudo R-squared & 0.0588 & 0.0685 & 0.168 & 0.173 & 0.0810 & 0.103 \\
\hline Log-likelihood & -127.7 & -126.4 & -80.51 & -80.08 & -106.0 & -103.5 \\
\hline
\end{tabular}

The coefficients reports the marginal effects from probit estimations. Robust standard errors in parentheses, $* * *$ $\mathrm{p}<0.01, * * \mathrm{p}<0.05, * \mathrm{p}<0.1$ 